\title{
Optimalt kan ikke bli bedre
}

\author{
Optimal er blitt et moteord. Men det er fort gjort å bruke det feil.
}

«Lege og kostholdsekspert Fedon Lindberg mener det mest optimale» er å ha et D-vitaminnivå i øvre del av dagens normalområde, sto det i avisen (1). Det burde det ikke ha gjort. Uttrykket «det mest optimale» blir smør på flesk. Ordet optimal stammer fra latin og betyr best, gunstigst. Språkviterne sier at det har superlativistisk betydning. Ordet lar seg derfor ikke gradere (2). I eksemplet blir det som om vi skulle si «det mest beste». I avisen burde det derfor stått «Lindberg mener det optimale er å ha ...».

Feilen er blitt vanlig. I tekstarkivet Retriever gir f.eks. «så optimalt som mulig» ca. 300 treff. Parkeringsplassen ved Oslo kommunale legevakt er «lite optimal», heter det i Aftenposten (3). « $\AA$ gjøre den perfekte korsbåndoperasjon er veldig vanskelig. Jeg forsøker å gjøre det så optimalt som mulig, og vil påstå at operasjonene i gamle dager var langt dårligere» (4) og «For å få maksimal effekt av forebyggende medisin må fosterets miljø fra befruktningstidspunktet være så optimalt som mulig» (5) er noen eksempler. Man burde altså ha skrevet at parkeringsplassen ikke er optimal og at fosterets miljø må være optimalt. Eller hva med å droppe moteordet (6) og heller skrive: Fosterets miljø må være best mulig.

Adjektivet optimal gradbøyes slik: bonus (god) - melior - optimus. Superlativen optimus betyr best, og det avledede adjektivet optimal betyr som er best. «Mest mulig optimal» og liknende graderinger blir da en pussighet (7). Hvis noe er perfekt, er det ingen grunn til å forbedre eller forsterke det ved å gjøre det så «optimalt som mulig». Det kan nemlig ikke bli bedre (8).

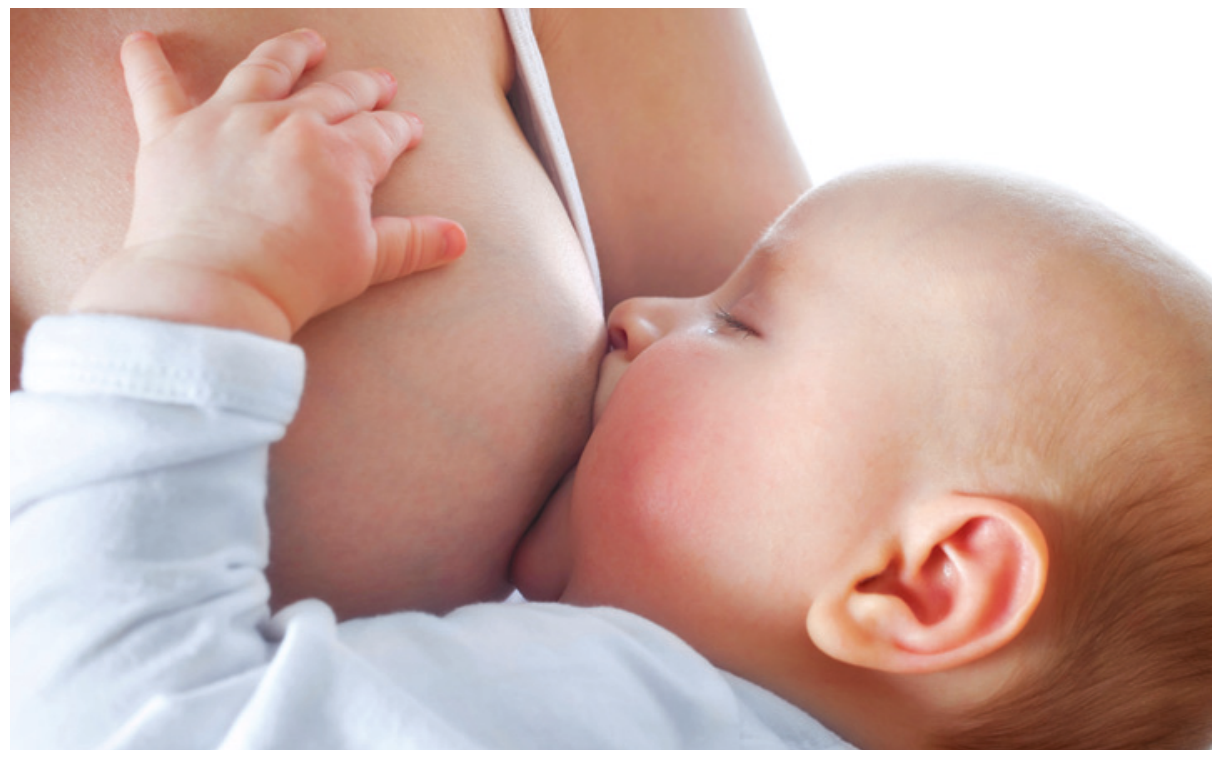

Optimalt sugetak. Det kan ikke bli bedre. Foto: thinkstock

Erlend Hem

erlend.hem@medisin.uio.no

Erlend Hem (f. 1970) er assisterende sjefredaktør i Tidsskriftet.

\section{Litteratur}

1. Brøyn MB. A for en strålende D-dag! Aftenposten 18.3.2014: 12. www.aftenposten.no/fakta/innsikt/ A_-for-en-stralende-D-dag-7506146.html (1.4.2014).

2. Vinje F-E. Riktig norsk. 3. utg. Oslo: Cappelen Akademisk, 1999: 106

3. Respektløst ved Legevakten. Aftenposten aften 2.12.2010: 3 .
4. Nydal TR. Slik svarer han. Bergensavisen 20.2.2013: 42

5. Henriksen T. Født sånn er mer enn gener. Aftenposten 21.10.2012: 4-5. www. aftenposten.no/ kronikker/Fodt-sann-er-mer-enn-gener-7023562 html (1.4.2014)

6. Hem E. Styr unna moteordene. Tidsskr Nor Legeforen 2012: 132: 1128-9.

7. Vinje F-E. Optimal. Finn-Erik Vinjes blogg 21.10.2012. www. finnerikvinje.no/blog/? $p=8037$ (1.4.2014).

8. Hegge PE. Språket vårt: Punktsystemer. Aftenposten morgen 31.3.2005: 4

http://tux.aftenposten.no/spraak/

spraak? action=question\&id=1806 (1.4.2014).

Mottatt 1.4. 2014 og godkjent 7.4. 2014. Redaktør: Marit Fjellhaug Nylund. 